trajectories demonstrated that 3683 of the stable, disease-associated chromosomal loops were shared by all 3 . However, 4496 were associated with distinct response trajectories, with 1221, 2574 and 701 loops unique to R, NR and IR respectively.

Conclusion: The stable chromosomal architecture unique to each treatment trajectory suggests that various underlying molecular endotypes may exist. Moreover, the stable loops common to all groups allude to a baseline level of dysregulation in RA and offers the potential to discover novel drivers of disease. This work provides the foundation to further our understanding of RA pathogenesis and the potential of finding a biomarker that would be of significant value in a clinical setting.

References:

[1] Carini, C., Hunter, E., Scottish Early Rheumatoid Arthritis Inception cohort Investigators, Ramadass, A. S., Green, J., Akoulitchev, A., et al. (2018). Chromosome conformation signatures define predictive markers of inadequate response to methotrexate in early rheumatoid arthritis. Journal of Translational Medicine, 16(1), 18-11

[2] Walsh, A. M., Whitaker, J. W., Huang, C. C., Cherkas, Y., Lamberth, S. L., Brodmerkel, C., et al. (2016). Integrative genomic deconvolution of rheumatoid arthritis GWAS loci into gene and cell type associations. Genome Biology, 17(1), 2205

Disclosure of Interests: Caitlin Duncan: None declared, Ewan Hunter: None declared, Christina Koutsothanasi: None declared, Matthew Salter: None declared, Alexandre Akoulitchev: None declared, lain Mclnnes Grant/research support from: Bristol-Myers Squibb, Celgene, Eli Lilly and Company, Janssen, and UCB, Consultant of: AbbVie, Bristol-Myers Squibb, Celgene, Eli Lilly and Company, Gilead, Janssen, Novartis, Pfizer, and UCB, Carl Goodyear: None declared

DOI: 10.1136/annrheumdis-2020-eular.5714

\section{SAT0034 CLINICAL SIGNIFICANCE OF ANTI-CARBAMYLATED PROTEIN ANTIBODIES IN PREMENOPAUSAL RHEUMATOID ARTHRITIS WOMEN: RELATION TO DISEASE ACTIVITY AND BONE LOSS}

R. Elnemr ${ }^{1}$, R. Bastawy ${ }^{2}$, R. Ghazala ${ }^{3}$, M. Abdelrazek ${ }^{4}$, N. Elsawy ${ }^{5}{ }^{1}$ Faculty of Medicine, Alexandria University, Physical Medicine, Rheumatology and Rehabilitation, Alexandria, Egypt; ${ }^{2}$ Alexandria University, Alexandria, Egypt; ${ }^{3}$ Alexandria University, Medical Biochemistry, Alexandria, Egypt; ${ }^{4}$ Alexandria University, Alexandria, Egypt; ${ }^{5}$ Alexandria University, Alexandria, Egypt

Background: Anti carbamylated protein anti carP are present in patients with Rheumatoid Arthritis RA and are associated with erosions. However their association with systemic or local bone loss in RA patients is still not confirmed.

Objectives: The purpose of this study was to measure the serum level of anti carP in premenopausal women with RA and determine its relation to disease activity and bone loss.

Methods: This case control study was conducted on forty eight RA premenopausal female patients diagnosed according to 2010 ACR/EULAR criteria and forty eight ages and body mass index matched healthy premenopausal females. RA patients with other autoimmune diseases, viral hepatitis malignancy or erosive joint disease and systemic diseases that affect bone quality were excluded from the study. All RA women were subjected to history taking, clinical examination, assessment of disease activity using disease activity score-28 DAS28 and clinical disease activity index CDAl functional assessment using health assessment questionnaire $\mathrm{HAQ}$ physical activity assessment using international physical activity questionnaire short form IPAQ fatigue assessment using modified fatigue impact scale MFIS, routine laboratory investigations, serological tests as well as Anti carP using ELISA kit. Moreover the bone mineral density was measured by a lunar Prodigy Advanced DEXA scanner system and plain $\mathrm{x}$-ray of both hands and wrists in the anteroposterior view was done to assess the juxta articular osteopenia and erosions.

Results: Anti carP level was significantly higher in RA patients than in healthy controls table 1. The serum level of anti carP had a significant positive correlation with RA DAS, CDAI, HAQ, IPAQ, MFIS and erosion and joint space narrowing in original sharp score. Also the anti carP had a significant negative correlation with the bone mineral density BMD of spine. The AUC of anti carP level showed a high level of accuracy AUC 0.857 figure 1 and the calculated cutoff value $>65$ can precisely discriminate subjects with RA from those without RA with $85.42 \%$ sensitivity and $85.11 \%$ specificity.
Table 1. Comparison between the patient and healthy groups according to anti carp leve

\begin{tabular}{lcccc}
\hline Anti-carp & RA patients & Healthy control & $U$ & $p$ \\
\hline Min - Max & $15.0-90.0$ & $1.0-78.50$ & & \\
Mean \pm SD & $71.24 \pm 14.70$ & $45.99 \pm 21.99$ & $322.0^{*}$ & $<0.001^{*}$ \\
Median (IQR) & $72.75(70.5-78.3)$ & $55.0(32.5-61.5)$ & & \\
\hline
\end{tabular}

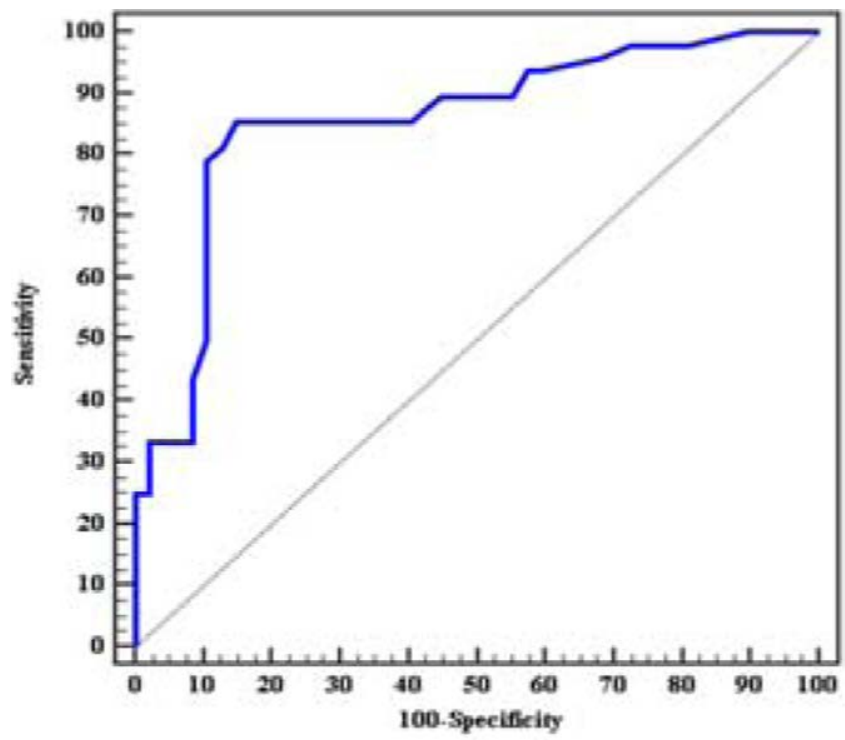

Figure 1. ROC curve for anti carP to diagnose RA patients from healthy subjects

Conclusion: Anti carbamylated antibodies were higher in premenopausal RA women compared to ages and body mass index matched healthy women. Anti carP are associated with higher RA disease activity, increased disability and decreased physical activity. Moreover anti carP are associated with systemic trabecular bone loss manifested by decreased bone mineral density of the spine as well as local bone loss as manifested by increased number of joint erosions in premenopausal RA women.

References:

[1] Regueiro C, Ortiz AM, Boveda MD, Castañeda S, Gonzalez-Alvaro I, Gonzalez A. Association of high titers of anti-carbamylated protein antibodies with decreased bone mineral density in early arthritis patients. PLoS ONE 2018; 13(8):e0202583.

Disclosure of Interests: None declared

DOI: 10.1136/annrheumdis-2020-eular.637

\section{SAT0035 RESPONSE TO ABATACEPT OF DIFFERENT PATTERNS OF INTERSTITIAL LUNG DISEASE IN RHEUMATOID ARTHRITIS: NATIONAL MULTICENTER STUDY OF 263 PATIENTS}

C. Fernández-Díaz ${ }^{1}$, S. Castañeda ${ }^{2}$, R. Melero ${ }^{2}$, J. Loricera ${ }^{2}$, F. OrtizSanjuán $^{2}$, A. Juan-Mas ${ }^{2}$, C. Carrasco-Cubero ${ }^{2}$, S. Rodriguéz-Muguruza ${ }^{2}$, S. Rodrigez-Garcia ${ }^{2}$, R. Castellanos-Moreira², R. Almodovar ${ }^{2}$, C. Aguilera Cros $^{2}$, I. Villa-Blanco², S. Ordoñez ${ }^{2}$, S. Romero-Yuste ${ }^{2}$, C. Ojeda-Garcia ${ }^{2}$, M. Moreno ${ }^{2}$, G. Bonilla ${ }^{2}$, I. Hernández-Rodriguez ${ }^{2}$, M. Lopez Corbeto ${ }^{2}$, J. L. Andréu Sánchez ${ }^{2}$, T. Pérez Sandoval ${ }^{2}$, A. López Robles ${ }^{2}$, P. Carreira ${ }^{2}$ N. Mena-Vázquez ${ }^{2}$, C. Peralta-Ginés ${ }^{2}$, A. Urruticoechea-Arana ${ }^{2}$, L. M. Arboleya Rodríguez ${ }^{2}$, J. Narváez ${ }^{2}$, D. Palma Sanchez ${ }^{2}$, O. Maiz-Alonso², J. FernándezLeroy $^{2}$, I. Cabezas-Rodriguez ${ }^{2}$, I. Castellví ${ }^{2}$, A. Ruibal-Escribano², J. De DiosJiménez Aberásturi ${ }^{2}$, P. Vela-Casasempere ${ }^{2}$, C. González-Montagut Gómez ${ }^{2}, \mathrm{~J}$. M. Blanco ${ }^{2}$, N. Alvarez-Rivas ${ }^{2}$, N. Del-Val' ${ }^{2}$, M. Rodíguez-Gómez ${ }^{2}$, E. SalgadoPérez ${ }^{2}$, C. Fernández-López ${ }^{2}$, E. C. Cervantes Pérez ${ }^{2}$, A. Devicente-Delmas ${ }^{2}$, B. Garcia-Magallon ${ }^{2}$, C. Hidalgo ${ }^{2}$, S. Fernández ${ }^{2}$, R. López-Sánchez ${ }^{2}$,

E. García-Fernández ${ }^{2}$, S. Castro², P. Morales-Garrido², A. García-Valle²,

R. Expósito ${ }^{2}$, L. Exposito-Perez² , L. Pérez Albaladejo ${ }^{2}$, Á. García-Aparicio², M.

A. González-

Gay ${ }^{1}$, R. Blanco ${ }^{1} .{ }^{1}$ H. Marqués de Valdecilla, Spain; ${ }^{2}$ National Health

System, Spain 
Background: Interstitial Lung Disease (ILD) is a severe extraarticular manifestation of rheumatoid arthritis (RA). In this line, several radiological patterns of RA-ILD have been described: i) usual interstitial pneumonia (UIP), ii) nonspecific interstitial pneumonia (NSIP), iii) obliterating bronchiolitis, iv) organized pneumonia and mixed patterns. Abatacept (ABA) could be an effective and safe option for patients with RA-ILD, although the response in the different radiological patterns is not well defined.

Objectives: Our aim was to assess the response to ABA in different radiological patterns of ILD.

Methods: Observational retrospective multicenter study of RA-ILD treated with ABA. ILD was diagnosed by HRCT and classified by radiological patterns in 3 different subgroups of RA-ILD: a) UIP, b) NSIP and c) "other." ABA was used sc. or iv. at standard dose. We assessed: a) Dyspnoea (MMRC scale; significant variation $\geq 1$ ); b) Respiratory function tests (significant changes $\geq 10 \%$ in FVC and DLCO); c) HRCT imaging; d) DAS28 e)prednisone dose.

Variables were collected at months $0,3,6,12$ months and subsequently every 12 months until a maximum of 60 months.

Results: We included 263 patients: 106 UIP, 84 NSIP and 73 others (150 women / 113 men), mean age $64.64 \pm 10$ years. Total patients positive for RF or CCPA were $235(89.4 \%)$ and $233(88.6 \%)$, respectively. In 26 out of 263 patients, the development of ILD was closely related to the administration of sDMARDs (MTX $\mathrm{n}=11$ and LFN $\mathrm{n}=1$ ) or bDMARDs (ETN $n=5$, ADA $n=4$, CZP $n=2$ and IFX $n$ $=3$ ). Patient characteristics are shown in table 1. Figure 1 shows the evolution of the cases with available data after a mean follow-up of $22.7 \pm 19.7$ months. Mean DLCO and FVC remained stable in the 3 groups without statistically significant changes, and all the groups showed a statistically significant reduction in DAS28 and prednisone dose.

Conclusion: ABA could be a good choice of treatment in patients with RA-ILD independently of the radiological pattern of ILD.

Disclosure of Interests: Carlos Fernández-Díaz Speakers bureau: Brystol Meyers Squibb, Santos Castañeda: None declared, Rafael Melero: None declared, J. Loricera: None declared, Francisco Ortiz-Sanjuán: None declared, A. Juan-Mas: None declared, Carmen Carrasco-Cubero Speakers bureau: Janssen, MSD, AbbVie, Novartis, Bristol Myers Squibb, and Celgene, S, Rodriguéz-Muguruza: None declared, S. Rodrigez -Garcia: None declared, R. Castellanos-Moreira: None declared, RAQUEL ALMODOVAR Speakers bureau: Abbvie, Celgene, Janssen, Lilly, Novartis, Pfizer.

, CLARA AGUILERA CROS: None declared, Ignacio Villa-Blanco Consultant of: UCB, Speakers bureau: Novartis, MSD, Lilly, Sergi Ordoñez: None declared, Susana Romero-Yuste: None declared, C. Ojeda-Garcia: None declared, Manuel Moreno: None declared, Gemma Bonilla: None declared, I. HernándezRodriguez: None declared, Mireia Lopez Corbeto: None declared, José Luis Andréu Sánchez: None declared, Trinidad Pérez Sandoval: None declared, Alejandra López Robles: None declared, Patricia Carreira Grant/research support from: Actelion, Roche, MSD, Consultant of: GlaxoSmithKline, VivaCell Biotechnology, Emerald Health Pharmaceuticals, Boehringer Ingelheim, Roche, Speakers bureau: Actelion, GlaxoSmithKline, Roche, Natalia Mena-Vázquez: None declared, C. Peralta-Ginés: None declared, ANA URRUTICOECHEAARANA: None declared, Luis Marcelino Arboleya Rodríguez: None declared, J. Narváez: None declared, DESEADA PALMA SANCHEZ: None declared, Olga Maiz-Alonso: None declared, J. Fernández-Leroy: None declared, I. Cabezas-Rodriguez: None declared, Ivan Castellví Consultant of: Boehringer Ingelheim, Actelion, Kern Pharma, Speakers bureau: Boehringer Ingelheim, Actelion, Bristol-Myers Squibb, Roche, A. Ruibal-Escribano: None declared, JR De Dios-Jiménez Aberásturi: None declared, Paloma Vela-Casasempere: None declared, C. González-Montagut Gómez: None declared, J M Blanco: None declared, Noelia Alvarez-Rivas: None declared, N. Del-Val: None declared, M. Rodíguez-Gómez: None declared, Eva Salgado-Pérez: None declared, Carlos Fernández-López: None declared, E.C. Cervantes Pérez: None declared, A. Devicente-DelMas: None declared, Blanca Garcia-Magallon Consultant of: MSD, Speakers bureau: Pfizer, Amgen, Celgene, MSD, Cristina Hidalgo: None declared, Sabela Fernández: None declared, R. López-Sánchez: None

\begin{tabular}{lccc}
\hline & UIP $(n=106)$ & NSIP $(n=84)$ & OTHERS (73) \\
\hline Sex (F/M) & $59 / 47$ & $49 / 35$ & $42 / 31$ \\
Age (years) & $66.8 \pm 10.0$ & $63.2 \pm 9.8$ & $65.0 \pm 9.9$ \\
RF/CCPA + (\%) & $94.4 / 92.3$ & $84.5 / 91.5$ & $87.7 / 86.1$ \\
Smoking or past smoking (\%) & $48.1 \%$ & $53.6 \%$ & $61.6 \%$ \\
Follow-up (months) & $20.37 \pm 17.85$ & $21.57 \pm 18.2$ & $27.25 \pm 22.4$ \\
DAS28 at baseline & $4.48 \pm 1.50$ & $4.42 \pm 1.47$ & $4.65 \pm 1.47$ \\
DAS28 at last visit & $2.99 \pm 1,27$ & $3.14 \pm 1.29$ & $3.21 \pm 1.47$ \\
Prednisone at baseline, median (IQR) (mg) & $7.5(5-10)$ & $10(5-10)$ & $7.5(5-10)$ \\
Prednisone at the end of study, median (IQR) (mg) & $5(2.5-5)$ & $5(2.5-10)$ & $5(2.5-7.5)$ \\
DLCO at baseline (\%) & $62.78 \pm 18.80$ & $65.01 \pm 21.14$ & $71.76 \pm 21.14$ \\
DLCO at the end of study (\%) & $62.04 \pm 18.86$ & $66.06 \pm 18.70$ & $70.07 \pm 22.19$ \\
FVC at baseline (\%) & $82.60 \pm 21.39$ & $89.47 \pm 19.39$ & $89.89 \pm 21.14$ \\
FVC at the end of study (\%) & $81.40 \pm 20.73$ & $87.86 \pm 22.65$ & $89.44 \pm 17.5$ \\
\hline
\end{tabular}

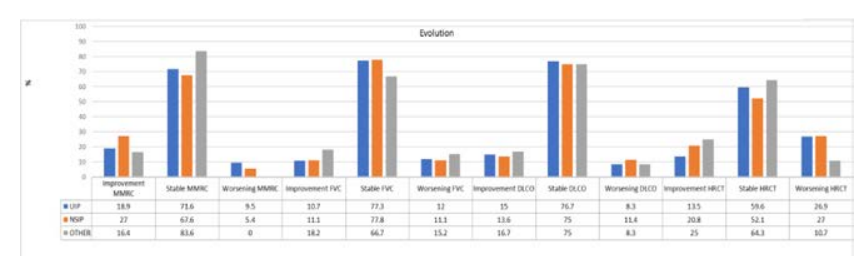

declared, Edilia García-Fernández: None declared, S. Castro: None declared,

P. Morales-Garrido: None declared, Andrea García-Valle: None declared, Rosa Expósito: None declared, L. Exposito-Perez: None declared, Lorena Pérez Albaladejo: None declared, Ángel García-Aparicio: None declared, Miguel A González-Gay Grant/research support from: Pfizer, Abbvie, MSD, Speakers bureau: Pfizer, Abbvie, MSD, Ricardo Blanco Grant/research support from: AbbVie, MSD, and Roche, Speakers bureau: AbbVie, Pfizer, Roche, BristolMyers, Janssen, and MSD

DOI: 10.1136/annrheumdis-2020-eular.1741

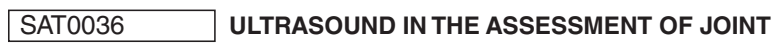 DAMAGE IN RHEUMATOID ARTHRITIS: A SYSTEMATIC LITERATURE REVIEW BY THE OMERACT ULTRASOUND WORKING GROUP}

I. GessI $^{1}$, B. Wildner ${ }^{2}$, P. Balint ${ }^{3}$, M. A. D'agostino ${ }^{4}$, P. Mandl ${ }^{1}{ }^{1}$ Medical University of Vienna, Div. of Rheumatology, Department of Internal Medicine III, Vienna, Austria; ${ }^{2}$ Medical University of Vienna, University Library, Vienna, Austria; ${ }^{3}$ National Institute of Rheumatology and Physiotherapy, 3rd Rheumatology Department, Budapest, Hungary; ${ }^{4}$ Hopital Ambroise Pare, Department of Rheumatology, APHP, Paris, France

Background: The detection of damage in patients with rheumatoid arthritis (RA) is crucial for monitoring of therapy targets as well as for early diagnosis. Conventional radiography $(\mathrm{CR})$ is commonly used to detect structural damage, in the form of bone erosions or loss of hyaline cartilage. Over the last years, musculoskeletal ultrasound (MSUS) was shown to be a sensitive and reliable method to detect erosion and cartilage loss as well as damage to soft tissue structures.

Objectives: To identify and synthesize the evidence for the use and measurement properties of MSUS in assessing structural damage in patients with RA.

Methods: A systematic literature search (SLR) of the PubMed, Embase and Cochrane Library was performed. Original articles were included that were published in English until 01/01/2019, reporting MSUS of bone erosion, cartilage loss or damage and tendon damage, and the measurement properties of MSUS according to the OMERACT Filter 2.1.

Results: Of the 1.266 identified articles 79 were finally included, most of which reported on cross-sectional studies. The majority of the studies used the OMERACT definitions for ultrasonographic pathology. Among these, erosions were assessed in $72(91.1 \%)$, cartilage damage in $12(15.2 \%)$, tendons in 4 $(5.1 \%)$ studies and enthesophytes in a single (1.3\%) study. Erosions were rated by binary grading in $56(77.8 \%)$ studies and by semiquantitative scoring in 27 $(37.5 \%)$ studies. Global or sum scores were calculated in only $9(12.5 \%)$ studies. Among 23 studies assessing erosions both by US and CR, only 1/23 (4.3\%) study found a higher sensitivity of CR as compared to MSUS. Among studies assessing tendons, 3 (75\%) used a semiquantitative score and one scored tendon rupture as being present or absent. Cartilage damage was graded in binary fashion, quantitatively by measuring cartilage thickness or semi-quantitatively. Hand joints were the most frequently evaluated joints (58, 73.4\%). The overwhelming majority of studies assessed structural damage bilaterally $(68,86.1 \%)$, with $5(6.3 \%)$ studies assessing only the dominant hand, $5(6.3 \%)$ studies evaluating the clinically more affected side and 1 (1.3\%) study assessing only the right hand. Validity, reliability and responsiveness were assessed in only $8(10.1 \%), 10(12.7 \%)$ and $4(5.1 \%)$ studies respectively. Feasibility was not considered in any of the studies.

Conclusion: While the results of this SLR suggest that US is a sensitive and feasible tool to detect damage in RA, they also highlight the need for further research and validation. Findings of this SLR will inform the next steps of the Working Group in developing an ultrasound score for assessing structural damage in patients with RA.

Disclosure of Interests: None declared DOI: 10.1136/annrheumdis-2020-eular.5712 